Scientific Review - Engineering and Environmental Sciences (2021), 30 (2), 283-292

Sci. Rev. Eng. Env. Sci. (2021), 30 (2)

Przegląd Naukowy - Inżynieria i Kształtowanie Środowiska (2021), 30 (2), 283-292

Prz. Nauk. Inż. Kszt. Środ. (2021), 30 (2)

http://iks.pn.sggw.pl

DOI 10.22630/PNIKS.2021.30.2.24

Muna H. AHMED, Ali M. Al-SALIHI, Hazim H. HUSSAIN

Mustansiriyah University, College of Sciences

\title{
Testing the performance of a solar energy cooling system in Baghdad city
}

Key words: cool buildings, solar chimney, ground heat exchanger, weather conditions

\section{Introduction}

The search for alternative ways to cool the air in the hot long season instead of using the electric power has become an important issue due to the severe shortage of electric power generation in the last two decades due to the deterioration of the infrastructure. According to Iraqi Meteorological Organization, the air temperature recordings in 2018 have exceeded $50^{\circ} \mathrm{C}$. Hence, adopting renewable energy technologies such as solar cooling is one of the good solutions to the power problem in the country. In addition to this good feature, using the renewable energy would reduce fossil fuel consumption and pollutant gas emissions into the atmosphere. The energy can have many forms such as kinetic, potential, electromagnetic, nuclear, sound, light or photo-energy, and gravitational (Mohamed, 2017). Energy is important issue for human development, and acts as a key factor in determining the economic development of all countries (Atwan, Kasim, Jasim \& Hameed, 2020). Fossil fuels are burned by power plants, transportation methods and by different industries. This results in emitting large amounts of pollutants, which endanger human health, has a negative impact on the economy and destroys the natural environment.

While most of today's energy is derived from fossil fuels, new technologies offer a range of electricity generation and cooling and heating options where they are required. These new options contain renewable energy technologies (Haghighi \& Maerefat, 2015). Internal conditions in most buildings are uncomfortable because of extreme outdoor weather conditions and the incorrect locations of windows and doors that implements natural ventilation (Zaidan, 
Abed \& Jasim, 2019). Consumption of high-grade energy has risen considerably with growing needs to obtain thermal comfort conditions inside buildings, residential complexes, greenhouses, cattle buildings, etc. (Bisoniya, 2015). Passive system terminology is applied to buildings that have, as integral parts, elements that admit, absorb, store, and emit solar energy; thus, reducing the need for more energy for comfort heating. These elements have something to do with the right orientation of the buildings, the right dimensions of openings, the use of terrace and other shading devices, and the use of insulation and thermal mass (Kalogirou, 2014). A passive strategy for cooling buildings can be obtained from natural ventilation. Effective ventilation and thermal comfort are of great significance in rural areas and in hot climate. One of the natural ventilation techniques that are used for conditioning buildings and which can participate to progress the energy efficiency of facilities are solar chimneys (Saifi, Settou, Dokkar, Negrou \& Chennouf, 2012). Solar chimney has been frequently adopted in buildings to save energy by enhancing the natural ventilation (Shi et al., 2019). It can be defined as a natural-draft system that uses solar radiation to move air upward and thus transforms solar energy into kinetic energy of air. The use of constant pressure air density decreases with the increase in temperatures. Air with higher temperature than that of ambient air is driven upwards by the buoyancy forces. A solar chimney makes use of this physical phenomenon (Charvat, Jicha \& Stetina, 2014). A second technique called ground heat exchanger, can be utilized which is a heat transfer device that exchanges heat between two or more process fluids (Zohuri, 2017). This technique is known by many different names such as the buried pipe system, underground air tunnel, earth tube heat exchanger and earth air tunnel. A variety of applications such as building thermal comfort, animal residence and agricultural greenhouses utilizes this system (Taib, Anuar \& Ibrahim, 2015). It is an ancient technique that has been used for thousands of years with high efficiencies especially in the hotter and drier climates (Ariffin, Sanusi \& Noor, 2014). The cooling tubes system consists of long pipes buried underground with one end connected to the house and the other end to the outside (Zaki, Amjad \& Almssad, 2007). Passive techniques are used to decrease the effect of the climate impacts on buildings by using insulating materials and air control system, which mean saving energy and reducing the demanded for cooling (Abed, Zaidan \& Jasim, 2019). This system works automatically as a result of the pressure difference between hot and cold air as the air flows from areas of higher pressure (cold air) to areas of lower pressure (hot air).

Our research aims to design a cooling system that depends on water and solar energy that can be used to cool houses or poultry fields and other facilities in areas adjacent to rivers, lakes, marshes and other water bodies.

Correlation in the broadest sense is a measure of an association between variables. In correlated data, the change in the magnitude of one variable is associated with a change in the magnitude of another variable, either in the same (positive correlation) or in the opposite (negative correlation) direction. Most 
often, the term correlation is used in the context of a linear relationship between two continuous variables and expressed as Pearson product-moment correlation (Schober, Boer \& Schwarte, 2018). The correlation coefficient $(r)$ is a test of the linear relationship between the calculated and measured value which is defined by:

$$
r=\frac{\sum_{i=1}^{N}\left(y_{i}-\bar{y}\right)\left(x_{i}-\bar{x}\right)}{\left[\left\{\left[\sum_{i=1}^{N}\left(y_{i}-\bar{y}\right)\right]\right\}\left\{\left[\sum_{i=1}^{N}\left(x_{i}-\bar{x}\right)\right]\right\}\right]^{0.5}}
$$

where:

$N$ - number of the values,

$y_{i}-$ estimated value,

$x_{i}$ - measured value,

$\bar{y}-$ mean value of the estimated values, $\bar{x}-$ mean value of the measured values.

\section{Material and methods}

The current study was carried out in Baghdad during April and May 2020. The constructed design is an innovative cooling system that consists of a test room, a chimney and a heat exchanger (Figs. 1 and 2). The test room $\left(1 \mathrm{~m}^{3}\right.$ size (1) volume) was built by using sandwich

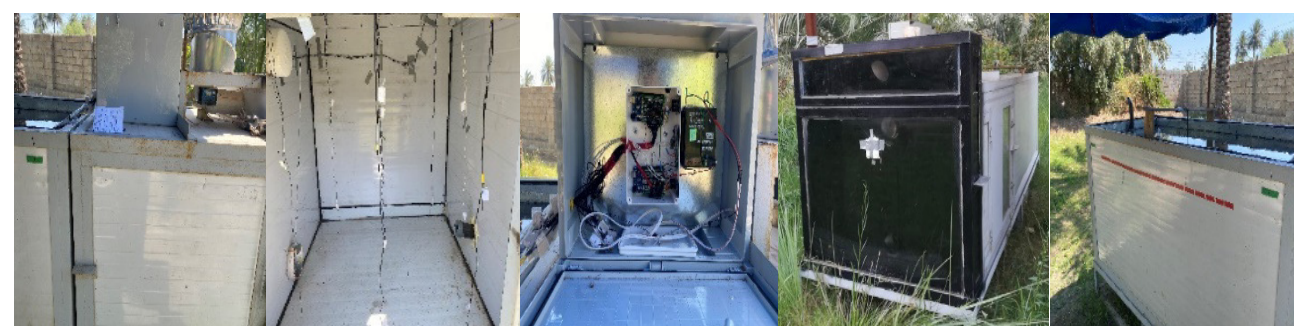

FIGURE 1. Images of the system

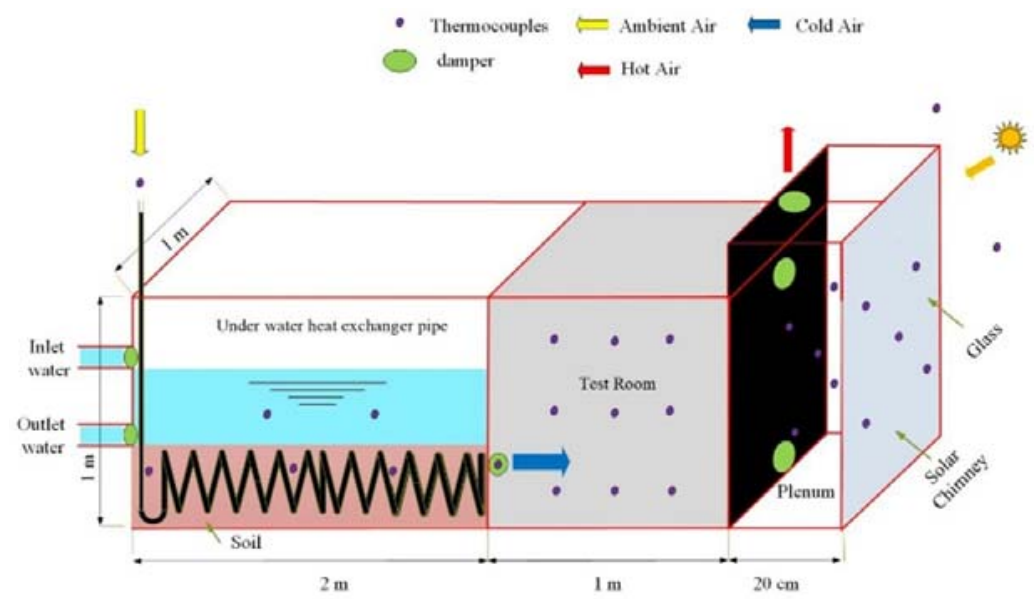

FIGURE 2. The system diagram 
panel material with a thickness of $5 \mathrm{~cm}$. This room is connected to a solar chimney $(20 \mathrm{~cm}$ length, $1 \mathrm{~m}$ width and $1 \mathrm{~m}$ height). The front side of the chimney was made of glass panels facing the geographical South. The other side consists of a metal plate painted black to enhance the absorption of solar energy during daytime. The heat exchanger was made of aluminum pipe (16 m length, $20 \mathrm{~cm}$ diameter).

The air inside the chimney heats up, rises and floats to the top of the chimney and exits from the ventilation hole. This movement of air will lead to an imbalance in air pressure causing to draw the cold air from the test room through the heat exchanger. The latter was buried with a layer of $20 \mathrm{~cm}$ thick mixed soil placed at the bottom of a submerged basin. The heat exchanger inlet exposed to the outside air and the outlet is connected to the test room. The basin that contains the water and the heat exchanger was made of galvanized iron plates of $1 \mathrm{~mm}$ thick. It was surrounded from outside by a layer of mixed soil $5 \mathrm{~mm}$ thick. It is also insulated with a sandwich panel material $(2 \mathrm{~m}$ length, $1 \mathrm{~m}$ width, $1 \mathrm{~m}$ height). To study the effect of weather conditions on the performance of the system, the weather parameters such as solar radiation, ambient air temperature, wind speed and relative humidity were measured using an automatic weather station. In addition, a grid of 20 thermocouples were used to measure the temperature at the various parts of the system during test process. These parts include water and soil in the bottom of the water basin, inlet and outlet air, heat exchanger, test room and solar chimney. The measurements were recorded by
Data Locker that stores data and which powered by solar energy.

The efficiency of the cooling system $\left(E_{f f}\right)$ was calculated using the following equation (Zaidan et al., 2019):

$E_{\text {ff }}=\frac{\left(T_{\text {in }}-T_{\text {out }}\right)}{T_{\text {in }}-T_{w}} \cdot 100$

where:

$T_{\text {in }}$ - inlet air temperature of the heat exchanger,

$T_{\text {out }}$ - outlet air temperature of the heat exchanger + ,

$T_{w}$ - water temperature.

\section{Results and discussion}

The changes in temperatures of test room, chimney, water, air at heat exchanger inlet and outlet and the solar radiation for April are visualized in Figure 3. The results show that temperatures begin to rise gradually. Maximum temperatures were recorded to be $23.5^{\circ} \mathrm{C}$ in test room at $3 \mathrm{pm}, 56.95^{\circ} \mathrm{C}$ in chimney at $2 \mathrm{pm}$, $30.57^{\circ} \mathrm{C}$ for inlet air at $2 \mathrm{pm}, 18.36^{\circ} \mathrm{C}$ for water at $5 \mathrm{pm}$, and $19.43^{\circ} \mathrm{C}$ for outlet air at $5 \mathrm{pm}$. By the same approach, the results of May were also visualized in Figure 4. Maximum temperatures were recorded to be $27.01^{\circ} \mathrm{C}$ at $3 \mathrm{pm}$ at test room $56.76^{\circ} \mathrm{C}$ in the chimney at $2 \mathrm{pm}$, $33.97^{\circ} \mathrm{C}$ for in let air at $2 \mathrm{pm}, 21^{\circ} \mathrm{C}$ for water at $5 \mathrm{pm}$ and $22.08^{\circ} \mathrm{C}$ for outlet air at $5 \mathrm{pm}$. It is clear that the temperature of the system was changing according to the change in solar radiation. Those changes in the temperature are identical to those published in 2012 study (Saifi et al., 2012). 


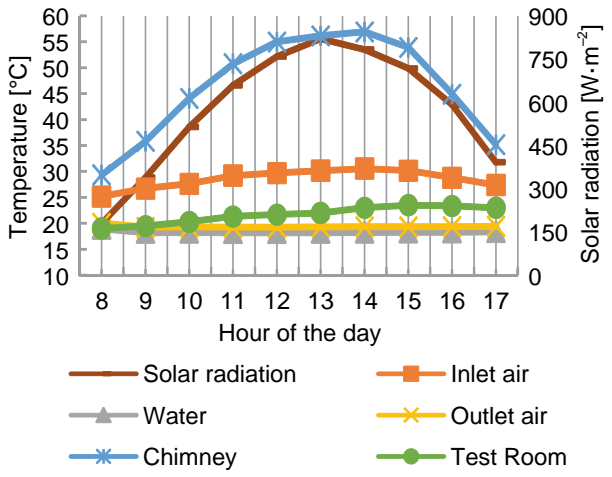

FIGURE 3. Temperature changes and solar radiation with the time in April 2020

The difference between test room temperature and ambient air temperature during April is shown in Figure 5. The minimum difference was recorded to be $3.2^{\circ} \mathrm{C}$ at 8 am while the maximum difference $\left(8.35^{\circ} \mathrm{C}\right)$ was recorded at $4 \mathrm{pm}$, it was during May. The minimum and maximum values of temperature were recorded to be 4.63 and $9.49^{\circ} \mathrm{C}$ at $8 \mathrm{am}$ and $5 \mathrm{pm}$, respectively (Fig. 6). Thus, it is obvious that temperature of the test room was less than that of the ambient air.

The effectiveness of the system was calculated as the rate during the period (April and May 2020) using Eq. (2) and

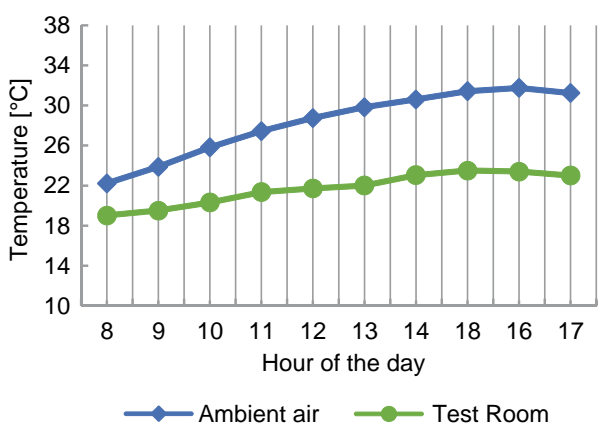

FIGURE 5. The difference in ambient air and test room temperature in April 2020

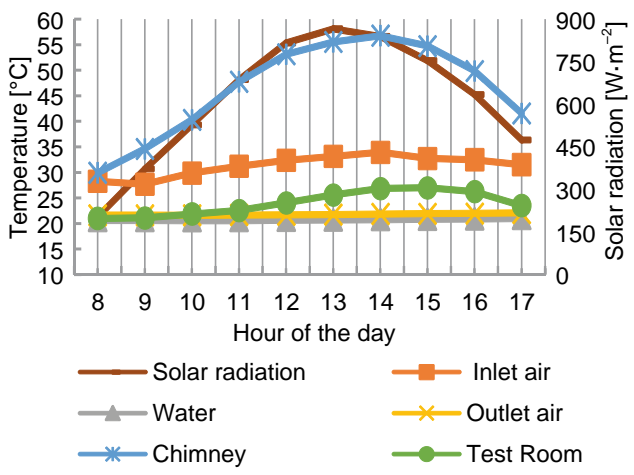

FIGURE 4. Temperature changes and solar radiation with time in May 2020

data in Table 1. The results of effectiveness for April and May were 89.01 and $89.5 \%$, respectively. The results are almost identical to those stated by Zaidan et al. (2019) where the cooling efficiencies were 92.6 and $90.05 \%$. A relationship was found between the cooling efficiencies and the factors related to the weather conditions by finding Pearson correlation coefficient in Eq. (1). Table 2 shows the weather data during study period. This relationship is seen in Figure 7 between the intensity of solar radiation and the efficiency of the system during daytime in April. A 0.91 correlation coefficient was obtained from the relationship between

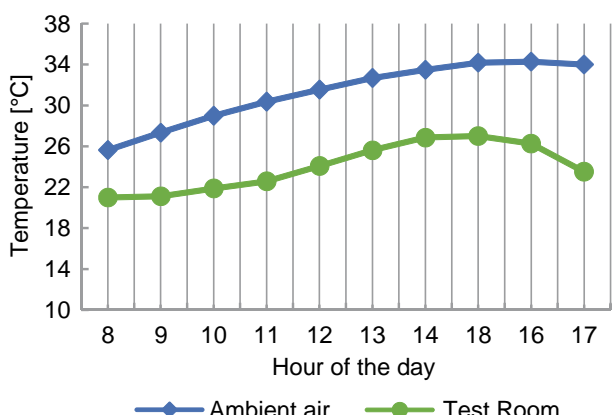

FIGURE 6. The difference in ambient air and test room temperature in May 2020 
TABLE 1. Temperatures of inlet air, water, outlet air and efficiency for April and May 2020

\begin{tabular}{|l|c|c|c|c|c|c|c|c|}
\hline \multirow{2}{*}{ Time } & \multicolumn{4}{|c|}{ April } & \multicolumn{5}{c|}{ May } \\
\cline { 2 - 10 } & $\begin{array}{c}\text { inlet air } \\
\text { tempera- } \\
\text { ture } \\
{\left[{ }^{\circ} \mathrm{C}\right]}\end{array}$ & $\begin{array}{c}\text { water } \\
\text { tempera- } \\
\text { ture } \\
{\left[{ }^{\circ} \mathrm{C}\right]}\end{array}$ & $\begin{array}{c}\text { outlet air } \\
\text { tempera- } \\
\text { ture } \\
{\left[{ }^{\circ} \mathrm{C}\right]}\end{array}$ & $\begin{array}{c}\text { tempera- } \\
\text { ture } \\
\text { efficiency } \\
{[\%]}\end{array}$ & $\begin{array}{c}\text { inlet air } \\
\text { tempera- } \\
\text { ture } \\
{\left[{ }^{\circ} \mathrm{C}\right]}\end{array}$ & $\begin{array}{c}\text { water } \\
\text { tempera- } \\
\text { ture } \\
{\left[{ }^{\circ} \mathrm{C}\right]}\end{array}$ & $\begin{array}{c}\text { outlet air } \\
\text { tempera- } \\
\text { ture } \\
{\left[{ }^{\circ} \mathrm{C}\right]}\end{array}$ & $\begin{array}{c}\text { tempera- } \\
\text { ture } \\
\text { efficiency } \\
{[\%]}\end{array}$ \\
\hline $08: 00$ & 25.20 & 18.98 & 20.03 & 83.11 & 28.30 & 20.60 & 21.66 & 86.23 \\
\hline $09: 00$ & 26.75 & 18.21 & 19.28 & 87.47 & 27.72 & 20.59 & 21.65 & 85.13 \\
\hline $10: 00$ & 27.66 & 18.25 & 19.33 & 88.52 & 29.91 & 20.57 & 21.64 & 88.54 \\
\hline $11: 00$ & 29.21 & 18.18 & 19.27 & 90.11 & 31.24 & 20.58 & 21.67 & 89.77 \\
\hline $12: 00$ & 29.73 & 18.18 & 19.27 & 90.56 & 32.40 & 20.63 & 21.72 & 90.73 \\
\hline $13: 00$ & 30.16 & 18.21 & 19.31 & 91.79 & 33.17 & 20.69 & 21.78 & 91.26 \\
\hline $14: 00$ & 30.57 & 18.25 & 19.35 & 90.07 & 33.97 & 20.77 & 21.87 & 91.66 \\
\hline $15: 00$ & 30.19 & 18.27 & 19.37 & 90.77 & 32.75 & 20.84 & 21.94 & 91.47 \\
\hline $16: 00$ & 28.82 & 18.30 & 19.39 & 89.63 & 32.48 & 20.91 & 22.00 & 90.57 \\
\hline $17: 00$ & 27.39 & 18.36 & 19.43 & 88.15 & 31.52 & 21.00 & 22.08 & 89.73 \\
\hline
\end{tabular}

TABLE 2. Weather data for April and May 2020

\begin{tabular}{|c|c|c|c|c|c|c|c|c|}
\hline \multirow[b]{2}{*}{ Time } & \multicolumn{4}{|c|}{ April } & \multicolumn{4}{|c|}{ May } \\
\hline & $\begin{array}{c}\text { ambient } \\
\text { air } \\
{\left[{ }^{\circ} \mathrm{C}\right]}\end{array}$ & $\begin{array}{c}\text { wind } \\
\text { speed } \\
{\left[\mathrm{m} \cdot \mathrm{s}^{-1}\right]}\end{array}$ & $\begin{array}{c}\text { solar } \\
\text { radiation } \\
{\left[\mathrm{W} \cdot \mathrm{m}^{-2}\right]}\end{array}$ & $\begin{array}{c}\text { relative } \\
\text { humidity } \\
{[\%]}\end{array}$ & $\begin{array}{c}\text { ambient } \\
\text { air } \\
{\left[{ }^{\circ} \mathrm{C}\right]}\end{array}$ & $\begin{array}{c}\text { wind } \\
\text { speed } \\
{\left[\mathrm{m} \cdot \mathrm{s}^{-1}\right]}\end{array}$ & $\begin{array}{c}\text { solar } \\
\text { radiation } \\
{\left[\mathrm{W} \cdot \mathrm{m}^{-2}\right]}\end{array}$ & $\begin{array}{c}\text { relative } \\
\text { humidity } \\
{[\%]}\end{array}$ \\
\hline 08:00 & 22.22 & 0.74 & 179.9 & 63.7 & 25.63 & 0.61 & 203.9 & 51.7 \\
\hline 09:00 & 23.87 & 0.87 & 339.1 & 60.3 & 27.34 & 0.97 & 372.8 & 49.4 \\
\hline 10:00 & 25.81 & 1.22 & 514.8 & 55.4 & 28.98 & 1.33 & 527.6 & 47.1 \\
\hline $11: 00$ & 27.44 & 1.68 & 659.4 & 52.0 & 30.36 & 1.51 & 687.0 & 43.7 \\
\hline $12: 00$ & 28.74 & 1.77 & 759.0 & 47.0 & 31.54 & 1.87 & 816.0 & 40.4 \\
\hline $13: 00$ & 29.82 & 1.59 & 821.0 & 43.4 & 32.68 & 2.05 & 866.1 & 38.0 \\
\hline $14: 00$ & 30.60 & 1.37 & 783.7 & 41.1 & 33.48 & 2.04 & 839.3 & 35.7 \\
\hline $15: 00$ & 31.42 & 1.32 & 718.1 & 38.5 & 34.18 & 1.99 & 754.1 & 33.4 \\
\hline 16:00 & 31.75 & 1.33 & 592.1 & 37.1 & 34.28 & 1.86 & 634.5 & 33.8 \\
\hline $17: 00$ & 31.24 & 1.33 & 392.2 & 36.1 & 34.00 & 2.59 & 474.4 & 33.0 \\
\hline
\end{tabular}

them. This indicates that the relationship is very strong, which means that solar radiation is the most important element of the weather condition affecting the system. The results also proved that there is a direct relationship between the inten- sity of solar radiation and the efficiency of the system's efficiency in May during daylight hours, correlation coefficient reached 0.89, as seen in Figure 8.

Figure 9 shows the relationship between temperature and system effective- 


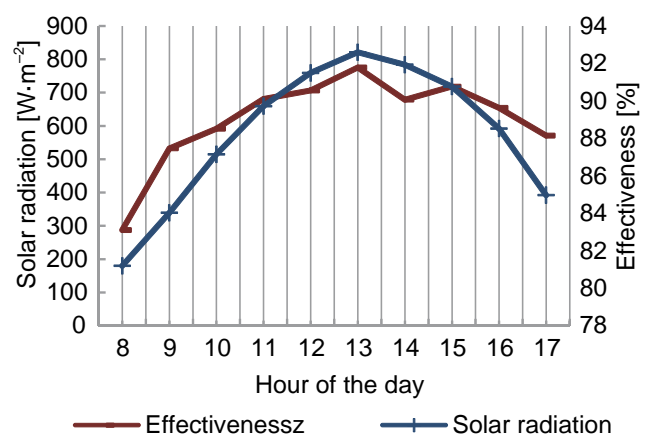

FIGURE 7. The relationship between solar radiation and cooling efficiency in April 2020

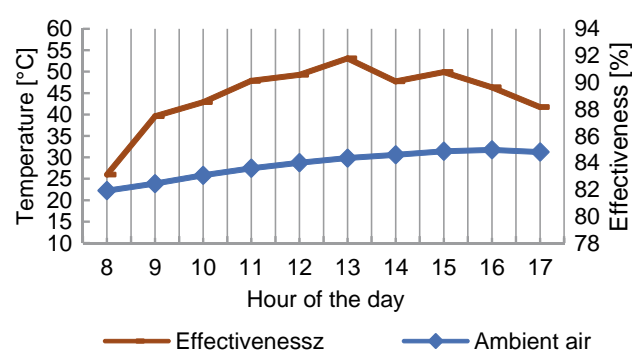

FIGURE 9. The relationship between temperature and cooling efficiency in April 2020

ness changes in April. This relationship has a positive direct correlation coefficient of 0.747 . Another relationship between the system's efficiency and temperature in May can be established (Fig. 10). This relationship was positive, and the correlation coefficient of 0.882 . This indicates that the increase in temperature lead to the increased of evaporation documenting the efficiency of the system.

Moreover, another relationship between the efficiency and wind speed in April was established as seen in Figure 11. The relationship was found to be direct and the correlation coefficient is 0.82 . Figure 12 demonstrates the rela-

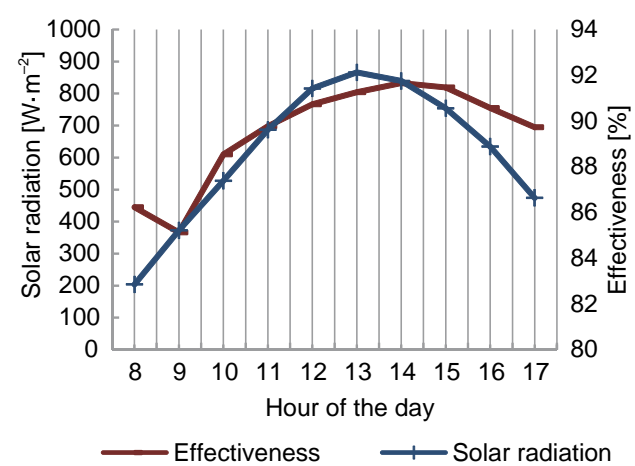

FIGURE 8. The relationship between solar radiation and cooling efficiency in May 2020

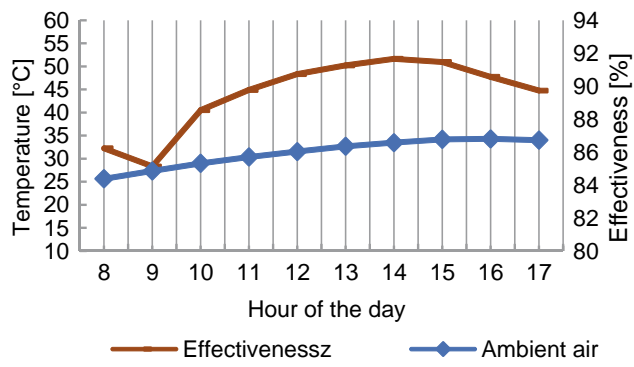

FIGURE 10. The relationship between temperature and cooling efficiency in May 2020

tionship between system efficiency and wind speed in May. The relationship is direct and the correlation coefficient is 0.814 . The increase in wind speed leads to increase in evaporation and hence enhances the efficiency.

Figure 13 shows the relationship between system efficiency and relative humidity in April. The relationship was found to be negative, and the correlation coefficient of -0.665 . Finally, the relationship between system efficiency and relative humidity in May were analyzed as shown in Figure 14. The figure indicates that the relationship was of a negative nature, and the correlation coefficient of -0.843 . 


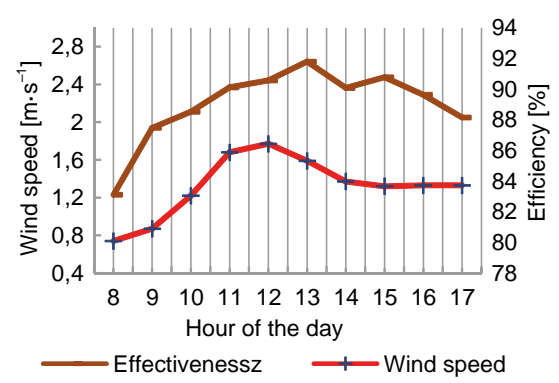

FIGURE 11. The relationship between wind speed and cooling efficiency in April 2020

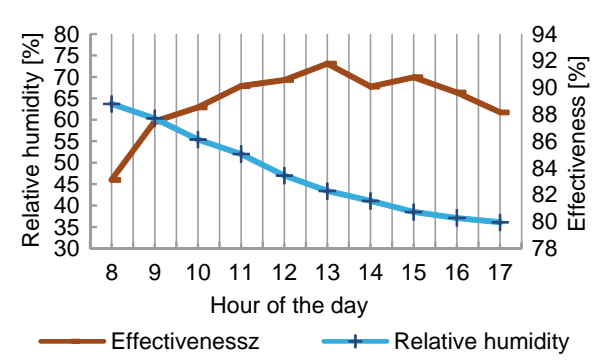

FIGURE 13. The relationship between relative humidity and cooling efficiency in April 2020

The reason for the negative relationship is the relative humidity reduces evaporation which occurs in the water basin. This process is inertial as it does not increase the water temperature (cooling). The heat that water gains from ambient air is lost by evaporation, which makes the water maintain its relative temperatures.

\section{Conclusions}

1. The system showed a significant difference in the air temperatures between the test room and the ambient air for April and May 2020. The maximum difference was $8.35^{\circ} \mathrm{C}$ at $4 \mathrm{pm}$ in April and $9.49^{\circ} \mathrm{C}$ at $5 \mathrm{pm}$ in May.

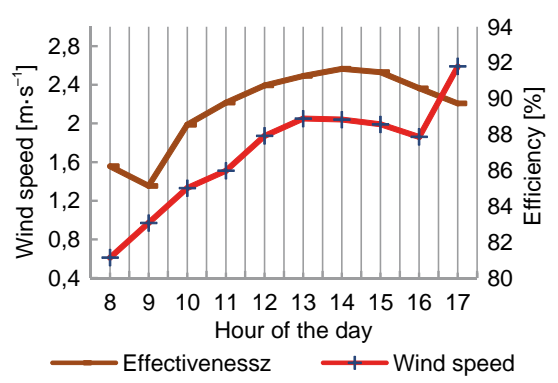

FIGURE 12. The relationship between wind speed and cooling efficiency in May 2020

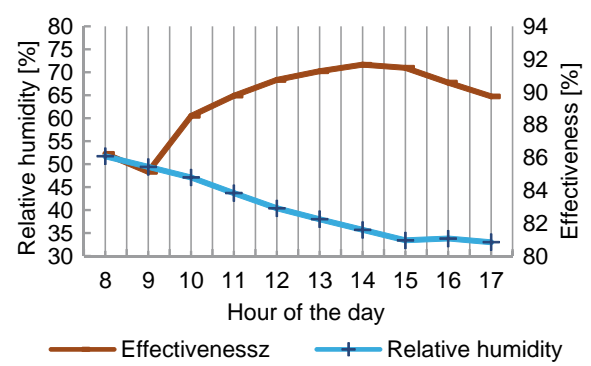

FIGURE 14. The relationship between relative humidity and cooling efficiency in May 2020

2. The cooling efficiency of the system reached maximum values of $89.01 \%$ in April and 89.5\% in May.

3. There was a positive direct relationship between cooling efficiency and the weather elements such as solar radiation, temperature and wind speed, the correlation coefficient was 0.91 , 0.747, 0.82 in April and 0.89, 0.882, 0.814 in May. However, there was a negative relationship between the system efficiency with relative humidity, the correlation coefficient was -0.665 in April and -0.84 in May.

\section{Acknowledgements}

Thanks for Mustansiriyah University (https://uomustansiriyah.edu.iq), Baghdad, Iraq for its support to complete this work. 


\section{References}

Abed, F.M, Zaidan, M.H. \& Jasim, A.K. (2019). Cooling building using a geothermal and underwater piping systems techniques (hot and dry weathers). Journal of Advanced Sciences and Engineering Technologies, 2(1), 13-28.

Ariffin, N.A.M., Sanusi, A.N.Z. \& Noor, A.M. (2014). Materials for the earth air pipe heat exchanger (EAPHE) system as a passive ground cooling technology for hot-humid climate. In Handbook on the Emerging Trends in Scientific Research (pp. 88-98). Singapore: PAK Publishing Group.

Atwan, A.F., Kasim, N.K., Jasim, N.A. \& Hameed, J.S. (2020). Improvement the PV solar module cooling systems by using shallow geothermal. AIP Conference Proceedings, 2290(1), 050028. https://doi. org/10.1063/5.0028808

Bisoniya, T.S. (2015). Design of earth-air heat exchanger system. Geothermal Energy, 3(1), $1-10$.

Charvat, P., Jicha, M. \& Stetina, J. (2004). Solar chimneys for ventilation and passive cooling. In A.A.M. Sayigh (ed.), Proceedings of the 8th World Renewable Energy Congress (WREC VIII): 28th August - 3rd September 2004, Denver, Colorado, USA. Retrieved from: https://www.researchgate.net/profile/Pavel -Charvat/publication/264882993 SOLAR CHIMNEYS FOR VENTILATION AND PASSIVE COOLING/links/53fdd $93 \mathrm{c} 0$ cf22f21c2f85410/SOLAR-CHIMNEYSFOR-VENTILATION-AND-PASSIVECOOLING.pdf [access 29.03.2020].

Haghighi, A.P. \& Maerefat, M. (2015). Design guideline for application of earth-to-air heat exchanger coupled with solar chimney as a natural heating system. International Journal of Low-Carbon Technologies, 10(3), 294-304.

Kalogirou, S.A. (2014). Solar energy engineering processes and systems. Cambridge (MA): Academic Press.

Mohamed, E.L.S. (2017). Economics of variable renewable sources for electric power production. Sunnyvale (CA): Lambert Academic Publishing.
Saifi, N., Settou, N., Dokkar, B., Negrou, B. \& Chennouf, N. (2012). Experimental study and simulation of airflow in solar chimneys. Energy Procedia, 18, 1289-1298.

Schober, P., Boer, C. \& Schwarte, L.A. (2018). Correlation coefficients: appropriate use and interpretation. Anesthesia \& Analgesia, 126(5), 1763-1768.

Shi, L., Cheng, X., Zhang, L., Li, Z., Zhang, G., Huang, D. \& Tu, J. (2019). Interaction effect of room opening and air inlet on solar chimney performance. Applied Thermal Engineering, 159, 113877. https://doi.org/ 10.1016/j.applthermaleng.2019.113877

Taib, M.Y., Anuar, S. \& Ibrahim, H. (2015). A review of ground heat exchangers for cooling application in the Malaysian climate. Journal of Mechanical Engineering and Sciences, 8, 1426-1439.

Zaidan, M.H., Abed, F.M. \& Jasim, A.K. (2019). Air-conditioning of buildings by using ground and water effects to drop down the inlet air temperature. Journal of Advanced Research in Fluid Mechanics and Thermal Sciences, 54(2), 165-174.

Zaki, A.K., Amjad, A.M. \& Almssad, A. (2007). Cooling by underground earth tubes. In M. Santamouris, P. Wouters (eds.), 2nd PALENC Conference and 28th AIVC Conference. on Building Low Energy Cooling and Advanced Ventilation Technologies in the 21st Century, 27-29 September 2007, Crete island, Greece. Book of Proceedings. Vol. 1 (pp. 517-520). Dafni-Athens: Heliotopos Conferences.

Zohuri, B. (2017). Heat exchanger types and classifications. In Compact Heat Exchangers: Selection, Application, Design and Evaluation (pp. 19-56). Cham: Springer.

\section{Summary}

Testing the performance of a solar energy cooling system in Baghdad city. Renewable energy resources have become a promissory alternative to overcome the problems related to atmospheric pollution and limited sources of fossil fuel energy. The 
technologies in the field of renewable energy are used also to improve the ventilation and cooling in buildings by using the solar chimney and heat exchanger. This study addresses the design, construction and testing of a cooling system by using the above two techniques. The aim was to study the effects of weather conditions on the efficiency of this system which was installed in Baghdad for April and May 2020. The common weather in these months is hot in Baghdad. The test room of the design which has a size of $1 \mathrm{~m}^{3}$ was situated to face the geographical south. The test room is thermally insulated and connected to a solar chimney which generates a convection current to draw the air out of the room through a heat exchanger. The heat exchanger was submerged in a water tank of $2 \mathrm{~m}$ length, $1 \mathrm{~m}$ width and $1 \mathrm{~m}$ height. It was also covered with a layer of soil mixture with a thickness of $10 \mathrm{~cm}$. The experiment simulates the natural conditions of a shallow water surface, connected to the room from the other side. The study results revealed that the air temperature inside the test room was lower than that of the ambient air outside. Pearson correlation coefficient showed that there was a strong direct relationship between solar radiation, temperature and wind speed from one side and the cooling efficiency from the other side. Also, there was a negative correlation between relative humidity and cooling efficiency.

\section{Authors' address:}

Muna H. Ahmed

Ali M. Al-Salihi

(https://orcid.org/0000-0002-6945-767X)

Hazim H. Hussain

(https://orcid.org/0000-0002-5588-8030)

Mustansiriyah University

College of Science

Atmospheric Sciences Department

Baghdad, Iraq

e-mail: mahmed@uomustansiriyah.edu.iq alialsalihi.atmsc@uomustansiriyah.edu.iq dr.hazim@uomustansiriyah.edu.iq 